\title{
Spinal Anesthesia in Vaginal Natural Orifice Transluminal Endoscopic Surgery: Experience of 12 Patients
}

\section{Vajinal Destekli Doğal Orifis Transluminal Endoskopik Cerrahide Spinal Anestezi: 12 Hasta Deneyimi}

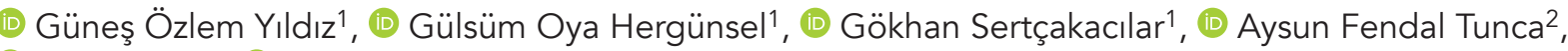 \\ (1) Cihan Kaya ${ }^{2}$, (1) Zafer Çukurova ${ }^{1}$ \\ ${ }^{1}$ University of Health Sciences Turkey, Bakirköy Dr. Sadi Konuk Training and Research Hospital, Clinic of Anesthesiology and Intensive Care, \\ İstanbul, Turkey \\ ${ }^{2}$ University of Health Sciences Turkey, Bakirköy Dr. Sadi Konuk Training and Research Hospital, Clinic of Gynecology and Obstetrics, İstanbul, \\ Turkey
}

\begin{abstract}
Objective: Vaginal natural orifice transluminal endoscopic surgery (vNOTES) is an alternative to conventional laparoscopy with less postoperative pain and shorter hospital stay. Limited data on the vNOTES under spinal anesthesia (SA) was reported. Thus, this study aimed to evaluate the feasibility, effectiveness, and side effects of SA in patients with gynecologic problems who underwent vNOTES.

Methods: SA was administered to the L1-L2 interspinous space in 12 patients with gynecologic problems who underwent vNOTES. Intrathecal $10 \mu \mathrm{g}$ of fentanyl $(0.2 \mathrm{~mL})$ and $0.5 \%$ of isobaric bupivacaine were administered. Patient demographic data, peroperative hemodynamic data, postoperative pain scores, and complications were retrospectively recorded.

Results: Between January 2019 and December 2019, gynecological surgery was successfully performed on 12 patients under SA via vNOTES. Right shoulder pain was observed in 3 patients (25\%) and anxiety in 1 patient (8\%), perioperatively. In the first 24 hours postoperatively, 1 patient (8\%) had a headache, whereas postoperative nausea and vomiting were not observed. None had pain requiring analgesia in the first 6 hours postoperatively.
\end{abstract}

Conclusion: SA is applicable for vNOTES.

Keywords: Analgesia, anesthesia, spinal, natural orifice endoscopic surgery, pain, postoperative, postoperative nausea and vomiting

\section{öz}

Amaç: Vajinal destekli doğal açıklık transluminal endoskopik cerrahi (vNOTES) tekniği, daha az postoperatif ağrı ve daha kısa hastanede kalış süresi ile geleneksel laparoskopik tekniğe bir alternatiftir. vNOTES tekniğinin spinal anestezi (SA) altında kullanımına ilişkin sınırlı veri vardır. Amacımız vNOTES tekniği ile ameliyat edilen jinekolojik hastalarda SA uygulanabilirliği etkinliğini ve yan etkilerini değerlendirmektir.

Gereç ve Yöntem: vNOTES tekniği ile ameliyat edilen 12 jinekolojik hastaya L1-L2 interspinöz aralıktan SA uygulandı. İntratekal $10 \mu \mathrm{g}$ fentanil $(0,2 \mathrm{~mL})$ ve \%0,5 izobarik bupivakain uygulandı. Hastaların demografik verileri, peroperatif hemodinamik verileri, postoperatif ağrı skorları ve komplikasyonlar geriye dönük olarak kaydedildi.

Bulgular: Ocak 2019-Aralık 2019 tarihleri arasında 12 hastaya SA altında vNOTES tekniği ile jinekolojik cerrahi başarıyla uygulandı. Ameliyat sırasında 3 hastada (\%25) sağ omuz ağrısı ve 1 hastada (\%8) anksiyete görüldü. Postoperatif ilk 24 saatte 1 hastada (\%8) baş ağrısı olurken postoperatif bulantı ve kusma izlenmedi. Postoperatif ilk 6 saatte hiçbir hastada analjezi gerektiren ağrı olmadı.

Sonuç: SA, vNOTES tekniği için uygulanabilineceğini düşünmekteyiz.

Anahtar Kelimeler: Analjezi, anestezi, spinal, doğal ağızı endoskopik cerrahi, ağrı, postoperatif, postoperatif bulantı ve kusma

Address for Correspondence: Güneş Özlem Yıldız, University of Health Sciences Turkey, Bakirköy Dr. Sadi Konuk Training and Research Hospital, Clinic of Anesthesiology and Intensive Care, İstanbul, Turkey

E-mail: drgunesim@hotmail.com ORCID ID: orcid.org/0000-0002-4557-9517

Cite as: Yıldız GÖ, Hergünsel GO, Sertçakacılar G, Fendal Tunca A, Kaya C, Çukurova Z. Spinal Anesthesia in Vaginally Assisted Natural Orifice Transluminal Endoscopic Surgery: An Experience of 12 Patients. Med J Bakirkoy 2021;17:197-202

Received: 01.03.2021

Accepted: 22.09.2021 


\section{INTRODUCTION}

The development of surgical techniques and technology allowed surgeons to perform an increased number of minimally invasive surgeries. In addition, it affected and improved anesthesia management. Conventional laparoscopy (CL) was reported to reduce postoperative morbidity, pain, and complications shorten the hospital stay and reduce the total cost compared to laparotomy $(1,2)$.

However, hemodynamic and physiological effects of $\mathrm{CL}$ due to pneumoperitoneum with carbon dioxide insufflation pose difficulties for anesthetists in terms of hypercarbia and venous gas embolism $(3,4)$.

In recent years, vaginal natural orifice transluminal endoscopic surgery (VNOTES) is a new developing alternative to $\mathrm{CL}$. vNOTES is a minimally invasive surgery that allows transgastric or transvaginal access using endoscopes without skin incision $(5,6)$. To date, minimal surgical trauma, early mobilization, less pain, and cosmetic benefits were reported in cholecystectomy, appendectomy, hysterectomy, and bilateral salpingoophorectomy cases performed via vNOTES $(6,7)$.

Today, general anesthesia (GA) is the preferred route of anesthesia induction in minimally invasive surgeries $(8,9)$ to reduce the risk of aspiration and abdominal discomfort, provide better bowel relaxation, and prevent hypercapnia due to carbon dioxide (CO2) during pneumoperitoneum $(5,10)$. However, spinal anesthesia $(S A)$ is an alternative, considering GA-related complications, in patients with respiratory distress and comorbidities. SA offers the advantages of less postoperative pain, nausea, and vomiting and early ambulation compared to GA $(11,12)$. Previous studies reported that SA is utilized safely with less postoperative pain, fewer respiratory complications, and affordable cost in $C L$ cases $(13,14)$.

CO2 insufflation and Trendelenburg position are used to adequately display the abdominal cavity, as in the $\mathrm{CL}$, in vNOTES. However, vNOTES was reported to provide better respiratory functions in the perioperative period due to lower intraabdominal pressure, shorter operative time, less perioperative opioid requirement, and less Trendelenburg position compared to $\mathrm{CL}(5,7)$.

Currently, limited literature is reported regarding the feasibility of vNOTES in gynecologic practice conducted with SA. Thus, this study aimed to evaluate the feasibility, effectiveness, and restrictions of SA for women who underwent the vNOTES technique.

\section{METHODS}

The ethical approval was obtained from University of Health Sciences Turkey, Bakirköy Dr. Sadi Konuk Training and Research Hospital Local Ethics Committee (protocal no: 2020/91), and the study was conducted with 12 patients having the American Anesthesiology Association (ASA) scores of 1-2, who were scheduled for benign gynecological pathology between January 2019 and December 2019. Investigate whether it complies with the 1964 Helsinki Declaration and the ethical standards of the national research committee.

The exclusion criteria were as follows: refusal to SA, any SA contraindications, coagulation disorder, cardiovascular diseases, history of local anesthetic allergies, and spinal deformities.

Information and written informed consent were obtained from patients regarding the SA and VNOTES procedures and conversion risk of GA in the presence of perioperative pain, severe anxiety, and abdominal discomfort.

The primary outcome was to evaluate the successful and safe applicability of SA in vNOTES cases. The secondary outcome was the visual analog scale (VAS) scores (VAS; 0 , no pain; 10, severe pain), mean heart rate, and mean arterial pressures during the surgery, presence of postoperative pain, and nausea or vomiting, and postoperative headache.

\section{Anesthesia Procedure}

All patients were monitored for vital parameters with electrocardiography, pulse oximetry, and non-invasive pressure monitoring in a supine position. An 18-gage intravenous (IV) vascular access was established, and crystalloid fluid was given at a rate of $8-10 \mathrm{~mL} / \mathrm{kg} / \mathrm{h}$ and sufficient hydration was provided for volume loading before SA (approximately 20-25 min). A $0.03 \mathrm{mg} / \mathrm{kg}$ IV midazolam was administered before the procedure to eliminate anxiety.

SA was administered in the sitting position, paying attention to adequate antiseptic rules. A midline approach through the L1-L2 spinous space was preferred. A 25-gage Quincke spinal needle was advanced to the dura mater, and a $0.5 \%$ isobaric bupivacaine $+10 \mu \mathrm{g}$ fentanyl was injected at $0.1 \mathrm{~mL} / \mathrm{s}$ after confirming a free and clear cerebrospinal fluid flow. The amount of bupivacaine was determined by the anesthetist, considering the patient's height, weight, age, and the intended target sensory anesthetic level (approximately $12.5-15 \mathrm{mg}$ of bupivacaine). Additional midazolam was given IV when a patient complains of increased anxiety during the operation.

All patients were placed in a supine position after the procedure. Anesthesia levels were evaluated with upper 
and lower sensory pinprick test and motor block with the modified bromage scale ( 0 : full flexion of the foot and knee; 1: knees and feet movements only; 2: no knee motion, just foot movement; and 3: full paralysis). When the sensory block reached the T4-5 level, the surgeon was allowed to start. All patients were noninvasively monitored for end tidal CO measurement (The ISA OR + sidestream multigaz analyzer Masimo Monitor Radikal 7; Masimo Corp., Irvine, CA, USA).

Adverse events during SA were treated as follows: 250 $\mathrm{mL}$ of isotonic saline infused over a 5-min period to treat hypotension [mean arterial pressure (MAP) $<60 \mathrm{mmHg}$ ], 5 milligrams of IV ephedrine if inadequate with a systolic blood pressure of $\leq 90 \mathrm{mmHg}, 0.5 \mathrm{mg}$ of atropine IV for bradycardia (50 beats $/ \mathrm{min}$ ), $1-2 \mu \mathrm{g} / \mathrm{kg}$ of fentanyl for shoulder pain or abdominal pain/discomfort, and $0.03 \mathrm{mg} / \mathrm{kg}$ of midazolam for anxiety. The intraabdominal $\mathrm{CO}_{2}$ pressure was set at $\leq 10 \mathrm{mmHg}$. Peak heart rate, non-invasive blood pressure, and peripheral oxygen saturation $\left(\mathrm{SpO}_{2}\right)$ values were recorded during the operation. Patient demographic data, perioperative anesthesia time, operative time, perioperative intraabdominal $\mathrm{CO}_{2}$ pressure, and complications were obtained from the anesthesia files. Postoperative pain was evaluated at 1, 6, 12, and 24 hours postoperatively as VAS1, VAS6, VAS12, and VAS24, respectively. Additional analgesic drug requirements, length of hospital stay, and presence of postoperative headache, nausea, and vomiting were obtained from the patients' medical records.

\section{NOTES Procedure}

A posterior colpotomy was performed in the dorsolithotomy position under SA. After revealing the cervix, the posterior lip was moved upwards using tenaculum forceps. A 2-3 cm posterior incision was performed. The vaginal mucosa was pushed with blunt and sharp dissections along with the cervical fascia. A self-constructed glove port with an X-Small Alexis Wound Retractor (Applied Medical, Rancho Santa Margarita, CA, USA) was inserted through the posterior colpotomy opening.

After achieving pneumoperitoneum, a $10 \mathrm{~mm}$, 30-degree telescope was inserted (Karl Storz visualization system; Karl Storz Tuttlingen, Germany). Disposable conventional laparoscopic grasping forceps, scissors, bipolar forceps, and tissue sealing devices were used. A suction-irrigation device was used as necessary.

\section{Statistical Analysis}

The analyses were performed using the Statistical Package for Social Sciences (SPSS) 20 for Windows (IBM SPSS Inc., Chicago, IL). The normal distribution of data was evaluated with the Kolmogorov-Smirnov test. Normally distributed numerical variables were shown as mean \pm standard deviation and minimum and maximum. Categorical variables were expressed as numbers and percentages.

\section{RESULTS}

The study group consisted of 12 patients who had ASA I (25\%) and ASA II (75\%). The mean age of the study population was $40.6 \pm 11.6$ years $(r=29-74)$ and the mean body mass index (BMI) was $25.9 \pm 5.5 \mathrm{~kg} / \mathrm{m}^{2}(\mathrm{r}=21-39)$. Of these 12 patients, $50 \%(n=6)$ had bilateral salpingoophorectomy, 25\% ( $n=3)$ had bilateral tubal ligation, 16\% ( $n=2)$ had salpingectomy due to ectopic pregnancy, and $8.3 \%(n=1)$ had unilateral salpingoophorectomy due to unilateral adnexial mass. No laparotomy or $\mathrm{CL}$ conversion was performed in any patients and no surgical complication was observed. The mean operative time was $37.2 \pm 12.7 \mathrm{~min}(\mathrm{r}=24-60)$. IV $1 \mu \mathrm{g} /$ $\mathrm{kg}$ of fentanyl was administered to 3 patients $(25 \%)$ due to perioperative shoulder pain complaints. None of the study participants developed respiratory depression and dyspnea. Hypotension (MAP $\leq 60 \mathrm{mmHg}$ ) and bradycardia (peak heart rate $\leq 50 / \mathrm{min}$ ) were not observed in any patient. No neurological deficits were observed on the neurological examinations performed postoperatively at 24 hours. The intraoperative data are presented in Table 1 and

Table 1. Perioperative findings

\begin{tabular}{lll}
\hline & Mean \pm SD or $\mathbf{n}(\%)$ & Min-max \\
\hline $\mathrm{HR} 1^{\text {st }}$ minute & $83.8 \pm 9.3$ & $69-98$ \\
\hline $\mathrm{HR} 10^{\text {th }}$ minute & $77.1 \pm 5.3$ & $65-83$ \\
\hline $\mathrm{HR} 20^{\text {th }}$ minute & $81.6 \pm 12.5$ & $65-101$ \\
\hline MAP $1^{\text {st }}$ minute & $90.1 \pm 15.4$ & $66-110$ \\
\hline MAP 10 ${ }^{\text {th }}$ minute & $81.7 \pm 14.1$ & $60-105$ \\
\hline MAP 20 ${ }^{\text {th }}$ minute & $77.9 \pm 9.7$ & $68-100$ \\
\hline SPO $1^{\text {st }}$ minute & $100 \pm 0$ & $100-100$ \\
\hline SPO ${ }_{2} 0^{\text {th }}$ minute & $100 \pm 0$ & $100-100$ \\
\hline SPO $20^{\text {th }}$ minute & $100 \pm 0$ & $100-100$ \\
\hline Intraabdominal pressure & $9.2 \pm 0.4$ & $9-10$ \\
\hline Operative time (min) & $37.3 \pm 12.7$ & $24-60$ \\
\hline $\begin{array}{l}\text { Additional fentanyl } \\
\text { requirement }\end{array}$ & $3(25 \%)$ & - \\
\hline Hypotension & - & - \\
\hline Bradycardia & - & - \\
\hline Nausea/Vomiting & - & - \\
\hline Respiratory depression & - & - \\
\hline
\end{tabular}

HR: Heart rate, MAP: Mean arterial pressure, $\mathrm{SPO}_{2}$ : Saturation of peripheral oxygen, Min-max: minimum-maximum, SD: Standart deviation 
Table 2. Postoperative findings

\begin{tabular}{lll}
\hline & Mean \pm SD & Min-max \\
\hline VAS1 & 0 & 0 \\
\hline VAS6 & $3.5 \pm 0.8$ & $2-5$ \\
\hline VAS12 & $4.4 \pm 0.9$ & $3-6$ \\
\hline VAS24 & $3.0 \pm 0.9$ & $2-4$ \\
\hline Analgesia requirement & $1(8.0 \%)$ & \\
\hline Hospital stay (day) & 1 & 1 \\
\hline Nausea/vomiting & - & - \\
\hline Headache & 1 (8.0\%) & - \\
\hline $\begin{array}{l}\text { VAS: Visual analog scale, min-max: minimum-maximum, SD: Standart } \\
\text { deviation }\end{array}$ & \\
\hline
\end{tabular}

postoperative findings are demonstrated in Table 2.

\section{DISCUSSION}

Our study revealed that SA is a feasible and effective alternative to GA in benign gynecologic cases operated via vNOTES. SA has become a preferred technique for patient comfort due to its advantages, such as ease of application, absence of hypertensive attacks due to sympathetic stimulation, less postoperative respiratory complications, low cost, early ambulation, and less postoperative pain compared to GA $(11,14,15)$. However, shoulder pain due to diaphragm irritation after $\mathrm{CO}_{2}$ insufflation and anxiety limit the applicability of SA in $C L(13,16)$. The incidence of shoulder pain for postoperative spinal and epidural anesthesia was reported to be 5.3\%-16.6\% $(17,18)$. A CL cholecystectomy study under thoracic SA revealed that $25 \%$ of patients had shoulder pain and were treated with fentanyl, as in our study (15).

Both SA and pneumoperitoneum have hemodynamic effects. SA causes hypotension due to sympathetic efferent blockade resulting in peripheral vasodilation (19). Using low pneumoperitoneum pressure in patients with adequate hydration decreases splanchnic blood volume and increases venous return, cardiac output, and arterial pressure $(14,20)$. In our study, patients were hydrated before SA was performed with 8-10 mL/ $\mathrm{kg}$ crystalloid fluid infusion, and low (8-10 $\mathrm{mmHg}$ ) pneumoperitoneum pressure was used. Therefore, decreased first measured MAP values of patients were observed; however, it was prevented from decreasing to values that require intervention (MAP $<60$ $\mathrm{mmHg}$ ). In addition, the SA level was controlled with isobaric bupivacaine, which prevents hypotension that occurs due to a sudden SA level rise.

Hyperbaric SA agent is not recommended for $C L$ cases since the Trendelenburg position causes cephalad spread of the regional anesthesia, causing a greater sympathetic block, bradycardia, and hypotension (4). In our study, isobaric bupivacaine was used and the operation was performed in around 15-degree Trendelenburg position. Thus, no drugrelated respiratory distress, respiratory depression, and cardiac problems were observed in our patients.

Nausea and vomiting appear after GA due to the effect of opioids, nitrogen protoxide, tramadol, and other used anesthetics, and postoperative antiemetic requirement increase, which delays the discharge. One of the advantages of $S A$ is the low incidence of postoperative nausea and vomiting (21). A study conducted by Cooper et al. (22) on patients who underwent cesarean with SA reported a statistically significant decreased intraoperative nausea by adding intrathecal fentanyl administration to the local anesthetic agent. None of our patients had nausea and vomiting during the perioperative period.

Under SA, the respiratory mechanism is preserved without significant change in the patient's ventilation parameters and $\mathrm{CO}_{2}$ levels. The study by Ciofolo et al. (23) investigated the effects of regional anesthesia on ventilation in patients who underwent CL. Arterial blood gases were examined during epidural anesthesia performed at different levels, Trendelenburg position, and $\mathrm{CO}_{2}$ insufflation. They reported no significant changes in ventilation parameters in the Trendelenburg position and respiratory rates. The ventilation in a minute increased during $\mathrm{CO}_{2}$ insufflation, without an increased $\mathrm{PCO}_{2}$ level during operation. According to their study, epidural anesthesia did not affect the ventilation values in CL cases and was a safe alternative to GA (23). Our study reported no problems with respiratory parameters and no increase in the end Tidal $\mathrm{CO}_{2}$ levels.

Postoperative pain management plays a key role in terms of hospital stay and risk of morbidity. Kalaivani et al. (24) prospectively compared SA and GA techniques in patients with cholecystectomy, which stated no pain in the first postoperative hours and within 8 hours in SA. However, $8 \%$ of patients had a VAS score of 4 and rescue analgesia was needed (24). The study by Symeonidis et al. (25) reported significantly lower pain scores at 4, 8, 12, and 24 hours postoperatively and postoperative opioid use was found to be statistically lower in the SA group compared to the GA group in patients who had a cholecystectomy.

To compare the results oflow and normal pneumoperitoneum pressure, Gurusamy et al. (26) reported that postoperative pain score, shoulder pain, and opioid use were lower in the group with low pressure $(<12 \mathrm{mmHg})$ compared to normal pneumoperitoneum pressure. Our study reported a low 
mean VAS score of patients and postoperative opioids were not used. We postulate that these low VAS scores are achieved due to SA and perioperative low abdominal pneumoperitoneum pressure as in the study by Gurusamy et al. (26).

\section{Study Limitations}

Our study had several limitations. Our study was conducted on patients with ASA1-2 and normal BMI to reveal the feasibility of the technique. SA is more appropriate than GA in patients with ASA3-4 and with obesity since these patients have more comorbidity to reduce the risk of postoperative respiratory distress. To generalize our findings, prospective studies with an increased number of patients are needed. In addition, the optimum sensory block level was not determined for vNOTES. The T4-T5 levels, which were determined for $\mathrm{CL}$ cases based on previous studies, are appropriate $(15,27)$. One of the most important side effects of SA is urinary retention. Moreover, the postoperative urinary retention data of patients were not analyzed. SA and GA should be compared in the same patient group to reach a more objective conclusion.

\section{CONCLUSION}

SA is used without any major complications as a feasible anesthesia technique in VNOTES gynecologic cases with tolerable postoperative pain and a more comfortable postoperative period.

\section{ETHICS}

Ethics Committee Approval: The study were approved by the University of Health Sciences Turkey, Bakirköy Dr. Sadi Konuk Training and Research Hospital of Local Ethics Committee (protocal no: 2020/91).

Informed Consent: All patients were informed and written informed consent was obtained.

\section{Authorship Contributions}

Surgical and Medical Practices: G.Ö.Y., Concept: G.Ö.Y., C.K., Design: G.Ö.Y., C.K., Data Collection or Processing: G.S., Analysis or Interpretation: C.K., Literature Search: G.Ö.Y., A.F.T., G.S., Writing: G.Ö.Y., G.O.H., Z.Ç.

Conflict of Interest: No conflict of interest was declared by the authors.

Financial Disclosure: The authors declared that this study received no financial support.

\section{REFERENCES}

1. Harrell AG, Lincourt AE, Novitsky YW, Rosen MJ, Kuwada TS, Kercher KW, et al. Advantages of laparoscopic appendectomy in the elderly. Am Surg 2006;72:474-80.
2. Zacks SL, Sandler RS, Rutledge R, Brown RS Jr. A population-based cohort study comparing laparoscopic cholecystectomy and open cholecystectomy. Am J Gastroenterol 2002;97:334-40.

3. Chui PT, Gin T, Oh TE. Anaesthesia for laparoscopic general surgery. Anaesth Intensive Care 1993;21:163-71.

4. Gerges FJ, Kanazi GE, Jabbour-Khoury SI. Anesthesia for laparoscopy: a review. J Clin Anesth 2006;18:67-78.

5. McGee MF, Rosen MJ, Marks J, Onders RP, Chak A, Faulx A, et al. A primer on natural orifice transluminal endoscopic surgery: building a new paradigm. Surg Innov 2006;13:86-93.

6. Clark MP, Qayed ES, Kooby DA, Maithel SK, Willingham FF. Natural orifice translumenal endoscopic surgery in humans: a review. Minim Invasive Surg 2012;2012:189296.

7. Schaefer M. Natural orifice transluminal endoscopic surgery (NOTES): implications for anesthesia. F1000 Med Rep 2009;1:80.

8. Kaya C, Alay I, Ekin M, Yaşar L. Hysterectomy by vaginal-assisted natural orifice transluminal endoscopic surgery: Initial experience with twelve cases. J Turk Ger Gynecol Assoc 2018;19:34-38.

9. Lee $\mathrm{CL}$, Wu KY, Su H, Wu PJ, Han CM, Yen CF. Hysterectomy by transvaginal natural orifice transluminal endoscopic surgery (NOTES): a series of 137 patients. J Minim Invasive Gynecol 2014;21:818-24.

10. Mehta N, Gupta S, Sharma A, Dar MR. Thoracic combined spinal epidural anesthesia for laparoscopic cholecystectomy in a geriatric patient with ischemic heart disease and renal insufficiency. Local Reg Anesth 2015;8:101-4.

11. Bessa SS, Katri KM, Abdel-Salam WN, El-Kayal el-SA, Tawfik TA. Spinal versus general anesthesia for day-case laparoscopic cholecystectomy: a prospective randomized study. J Laparoendosc Adv Surg Tech A 2012;22:550-5.

12. Yuksek YN, Akat AZ, Gozalan U, Daglar G, Pala Y, Canturk M, et al. Laparoscopic cholecystectomy under spinal anesthesia. Am J Surg 2008;195:533-6.

13. Sinha R, Gurwara AK, Gupta SC. Laparoscopic cholecystectomy under spinal anesthesia: a study of 3492 patients. J Laparoendosc Adv Surg Tech A 2009;19:323-7.

14. Kar M, Kar JK, Debnath B. Experience of laparoscopic cholecystectomy under spinal anesthesia with low-pressure pneumoperitoneum--prospective study of 300 cases. Saudi J Gastroenterol 2011;17:203-7.

15. van Zundert AA, Stultiens G, Jakimowicz JJ, Peek D, van der Ham WG, Korsten $\mathrm{HH}$, et al. Laparoscopic cholecystectomy under segmental thoracic spinal anaesthesia: a feasibility study. $\mathrm{Br} \mathrm{J}$ Anaesth 2007;98:682-6.

16. Yeh CC, Ko SC, Huh BK, Kuo CP, Wu CT, Cherng CH, et al. Shoulder tip pain after laparoscopic surgery analgesia by collateral meridian acupressure (shiatsu) therapy: a report of 2 cases. J Manipulative Physiol Ther 2008;31:484-8.

17. Imbelloni LE, Sant'anna R, Fornasari M, Fialho JC. Laparoscopic cholecystectomy under spinal anesthesia: comparative study between conventional-dose and low-dose hyperbaric bupivacaine. Local Reg Anesthm 2011;4:41-6.

18. Das W, Bhattacharya S, Ghosh S, Saha S, Mallik S, Pal S. Comparison between general anesthesia and spinal anesthesia in attenuation of stress response in laparoscopic cholecystectomy: A randomized prospective trial. Saudi J Anaesth 2015;9:184-8.

19. Toptaş $M$, Uzman $S$, İşitemiz I, Uludağ Yanaral T, Akkoç I, Bican G. A comparison of the effects of hyperbaric and isobaric bupivacaine spinal anesthesia on hemodynamics and heart rate variability. Turk J Med Sci 2014;44:224-31.

20. Donmez T, Erdem VM, Uzman S, Yildirim D, Avaroglu H, Ferahman $\mathrm{S}$, et al. Laparoscopic cholecystectomy under spinal-epidural 
anesthesia vs. general anaesthesia: a prospective randomised study. Ann Surg Treat Res 2017;92:136-42.

21. Sinclair DR, Chung F, Mezei G. Can postoperative nausea and vomiting be predicted? Anesthesiology 1999;91:109-18.

22. Cooper DW, Lindsay SL, Ryall DM, Kokri MS, Eldabe SS, Lear GA. Does intrathecal fentanyl produce acute cross-tolerance to i.v. morphine? Br J Anaesth 1997;78:311-3.

23. Ciofolo MJ, Clergue F, Seebacher J, Lefebvre G, Viars P. Ventilatory effects of laparoscopy under epidural anesthesia. Anesth Analg 1990;70:357-61.

24. Kalaivani V, Pujari VS, R SM, Hiremath BV, Bevinaguddaiah Y. Laparoscopic Cholecystectomy Under Spinal Anaesthesia vs.
General Anaesthesia: A Prospective Randomised Study. J Clin Diagn Res 2014;8:NC01-4.

25. Symeonidis D, Baloyiannis I, Georgopoulou S, Koukoulis G, Athanasiou E, Tzovaras G. Laparoscopic ventral hernia repair in obese patients under spinal anesthesia. Int J Surg 2013;11:926-9.

26. Gurusamy KS, Samraj K, Davidson BR. Low pressure versus standard pressure pneumoperitoneum in laparoscopic cholecystectomy. Cochrane Database Syst Rev 2009;(2):CD006930.

27. Jun GW, Kim MS, Yang HJ, Sung TY, Park DH, Cho CK, et al. Laparoscopic appendectomy under spinal anesthesia with dexmedetomidine infusion. Korean J Anesthesiol 2014;67:246-51. 